\title{
Widespread functional anoxia in the oxygen minimum zone of the Eastern South Pacific
}

\author{
Bo Thamdrup ${ }^{\mathrm{a}, *}$, Tage Dalsgaard ${ }^{\mathrm{b}}$, Niels Peter Revsbech ${ }^{\mathrm{c}}$ \\ a Nordic Center for Earth Evolution, Institute of Biology, University of Southern Denmark, Campusvej 55, 5230 Odense M, Denmark \\ ${ }^{\mathrm{b}}$ Department of Bioscience - Marine Ecology, Aarhus University, Vejlsøvej 25, 8600 Silkeborg, Denmark \\ ${ }^{\mathrm{c}}$ Department of Bioscience - Microbiology, Aarhus University, Ny Munkegade 116 Build. 1540, 8000 Aarhus C, Denmark
}

\section{A R T I C L E I N F O}

\section{Article history:}

Received 20 December 2011

Received in revised form

6 March 2012

Accepted 6 March 2012

Available online 16 March 2012

\section{Keywords:}

Oxygen minimum zone

Oxycline

Respiration

Nitrate reduction

Nitrite oxidation

\begin{abstract}
A B S T R A C T
Oxygen minimum zones (OMZs) as found in the Eastern Pacific and Indian Ocean are biogeochemical hot spots with a disproportionately large role in the marine nitrogen cycle, and they are important components of the highly productive ecosystems in which they occur. Although the oxygen-depleted waters have been known for a century, oxygen levels inside them are not well constrained and the regulation of their anaerobic processes by oxygen is poorly understood. We deployed highly sensitive STOX oxygen sensors with a detection limit of $10 \mathrm{nmol} \mathrm{kg}^{-1}$ in combination with conventional hydrographic oxygen sensors along a cruise track transecting the Eastern South Pacific OMZ from South to North along the coast of Chile and Peru. Oxygen was below the detection limit throughout the $\sim 200 \mathrm{~m}$ thick OMZ core in most casts with STOX sensors. The only exception was an offshore location off Peru where oxygen was $10-50 \mathrm{nmol} \mathrm{kg}{ }^{-1}$ in the core, likely as the result of a transient intrusion. Oxygen was also not detected in the OMZ core in further casts with conventional sensors, which had a detection limit of $90 \mathrm{nmol} \mathrm{kg}^{-1}$ after STOX-based zero calibration. Our measurements tighten the constraints on typical oxygen concentrations in the inner part of the OMZ by at least an order of magnitude relative to previous reports. Nitrite only accumulated when oxygen was depleted below $50 \mathrm{nmol} \mathrm{kg}{ }^{-1}$, which indicates that nitrogen cycling is much more sensitive to oxygen than previously estimated. We argue that extreme oxygen depletion to low nanomalar or even picomolar concentrations is a normal condition in the South Pacific OMZ, and suggest that the OMZ core is in fact functionally anoxic over wide regions for extended periods. Our results further indicate that oxygen dynamics in the low nanomolar range play an important role in OMZ biogeochemistry.
\end{abstract}

(c) 2012 Elsevier Ltd. All rights reserved.

\section{Introduction}

Following the first report of a pelagic oxygen minimum with "practically no oxygen at all" in the Pacific Ocean off Panama (Schmidt, 1925), similar conditions have been found to persist in wider parts of the Eastern North and South Pacific, in the Arabian Sea, and, to a lesser extent, in the South Atlantic off Namibia (Helly and Levin, 2004; Karstensen et al., 2008; Paulmier and Ruiz-Pino, 2009). These conditions result from a combination of stratification, sluggish circulation, and high oxygen consumption associated with organic matter sinking from productive surface waters (Wyrtki, 1962; 1967). Although waters of extreme oxygen depletion make up less than $0.1 \%$ of the ocean volume (Codispoti et al., 2001), they are important components of the marine

\footnotetext{
* Corresponding author. Tel.: +456550 2477; fax: +456550 2786 .

E-mail addresses: bot@biology.sdu.dk (B. Thamdrup), tda@dmu.dk (T. Dalsgaard), revsbech@biology.au.dk (N.P. Revsbech).
}

system. Thus, they support $25-50 \%$ of the removal of oceanic fixed nitrogen (Codispoti, 2007; Gruber, 2008) through anaerobic microbial processes including denitrification and anammox (Goering and Cline, 1970; Dalsgaard et al., 2003; Thamdrup et al., 2006) and are associated with a similar fraction of the oceanic $\mathrm{N}_{2} \mathrm{O}$ emission (Bange, 2008; Naqvi et al., 2010). Unique nitrate-dependent benthic microbial communities thrive where the oxygen-depleted waters impinge on the seafloor (Fossing et al., 1995; Høgslund et al., 2008), which is also an important site of phosphorite formation (Froelich et al., 1988; Föllmi, 1996).

Ongoing and forecasted expansions of OMZs (Stramma et al., 2008; 2010; Keeling et al., 2010) and of marine "dead zones" in general (Diaz and Rosenberg, 2008; Rabalais et al., 2010) emphasize the need for a detailed understanding of the role of these environments in the oceans. Fundamental to such an analysis are accurate definitions of oxygen distributions and dynamics within the OMZ, and how these conditions affect aerobic and anaerobic processes. Poor analytical resolution of oxygen at low concentrations is a major obstacle for further progress in this field (Ward 
et al., 2007; Jensen et al., 2008; Revsbech et al., 2009). Until recently, even very careful oceanographic surveys have reported detection limits for oxygen of about $1 \mu \mathrm{mol} \mathrm{kg}{ }^{-1}\left(0.02 \mathrm{~mL} \mathrm{~L}^{-1}\right)$ (Cline and Richards, 1972; Paulmier et al., 2006). This is at least one order of magnitude higher than the half-saturation coefficient of oxygen respiration and aerobic growth in some bacterial cultures (Lloyd, 2002; Stolper et al., 2010) and natural microbial communities (Clement et al., 2009; Revsbech et al., 2009), and hence too high to resolve the oxygen-dependence of this process. Likewise, substantial aerobic oxidation of nitrite, ammonium, and manganese takes place at oxygen levels below detection by conventional methods (Lipschultz et al., 1990; Lam et al., 2007; Clement et al., 2009).

The oxygen threshold for anaerobic microbial processes leading to $\mathrm{N}_{2}$ production in the $\mathrm{OMZ}$ is also not well defined. Recent OMZ budgets and models operate with thresholds ranging from 0.7 to $20 \mu \mathrm{mol} \mathrm{kg}^{-1}$ (see Karstensen et al., 2008; Paulmier and Ruiz-Pino, 2009). A high threshold is supported by some studies with pure cultures of denitrifiers (e.g., Betlach and Tiedje, 1981; Bonin et al., 1989), while the relative distribution of nitrite and oxygen in OMZs has been taken as an indication that nitrate reduction there is restricted to oxygen levels below 1$4.5 \mu \mathrm{mol} \mathrm{kg}{ }^{-1}$ (Cline and Richards, 1972; Morrison et al., 1999; Codispoti et al., 2001). Also the absence of fixed nitrogen removal in the Bay of Bengal OMZ despite oxygen depletion to $\sim 3 \mu \mathrm{mol} \mathrm{kg}^{-1}$, points to a high oxygen sensitivity of these processes (Naqvi et al., 2005), and so do the low half-saturation coefficients for aerobic respiration (refs. above), since a tight coupling is expected between the oxygen dependence of aerobic respiration and the onset of nitrate reduction (Devol, 1978). Better analytical sensitivity is thus required to resolve the transition between aerobic and anaerobic respiration in OMZs, and also to evaluate the potential for interactions of aerobes and anaerobes at nanomolar oxygen levels (Lipschultz et al., 1990; Lam et al., 2007). Such improvements might further help to resolve specific issues such as the surprising differences in the importance of denitrification and anammox in between different OMZs (Ward et al., 2009) and the diverging conclusions concerning the relative importance of these processes in the Arabian Sea (Ward et al., 2009; Jensen et al., 2011).

With a detection limit of $0.01 \mu \mathrm{mol} \mathrm{kg}{ }^{-1}$ or better, the newly developed STOX oxygen sensor greatly improves the prospects of resolving oxygen dynamics in OMZs and determing the oxygen dependence of microbial processes (Revsbech et al., 2009; 2011). In the first in situ deployment of the STOX sensor at a station off Peru, oxygen was not detectable $\left(<2 \mathrm{nmol} \mathrm{kg}^{-1}\right)$ through the OMZ core, i.e., the system was essentially anoxic (Revsbech et al., 2009). Oxygen was also not detected in the OMZ core in two further deployments off Chile (Canfield et al., 2010) nor in one in the Arabian Sea (Jensen et al., 2011), with detection limits of 13 and $90 \mathrm{nmol} \mathrm{kg}{ }^{-1}$, respectively, suggesting that extreme oxygen depletion may be a common phenomenon.

In order to provide a more detailed description of oxygen levels and their distribution in an OMZ core, and thereby more accurately define the conditions for biogeochemical processes, we used a combination of measurements with STOX and conventional sensors to determine oxygen along a transect through the $\mathrm{OMZ}$ of Eastern South Pacific from $5^{\circ}$ to $28^{\circ} \mathrm{S}$. We further used the relative distribution of oxygen and nitrite, the key intermediate in the reductive pathways of the nitrogen cycle, to analyze how oxygen affected the net balance of oxidative and reductive nitrogen metabolisms.

\section{Materials and methods}

All measurements were made between 12 and 24 February 2007 during legs 13 and 14 of the Danish Galathea-3 Expedition (Fig. 1; Table 1). STOX (Switchable Trace amount OXygen; Revsbech et al., 2009) and two Seabird SBE43 oxygen sensors were mounted on a Seabird SBE911 CTD (Conductivity-Temperature-Depth probe) associated with a SBE32 rosette carrying ten 30-L Niskin bottles. Sensor configuration, mounting, data aquisition, and calibration were previously described (Revsbech et al., 2009), except the zero correction of the SBE43 oxygen data, which is described below. Data for this study was acquired at a rate of $24 \mathrm{~s}^{-1}$ during the upward part of the hydrographic casts. STOX sensors contain a front guard cathode, which is intermittently polarized at $-0.8 \mathrm{~V}$ to keep oxygen from reaching the measuring cathode and permit zero calibration in situ. The sensors were operated in a $60 \mathrm{~s}$ cycle with the front guard cathode polarized for $20 \mathrm{~s}$ (zeroing) and depolarized for $40 \mathrm{~s}$ (measurement), and data collected from 6 to $1 \mathrm{~s}$ before each switch in polarization was used for oxygen determination (Revsbech et al., 2009). The

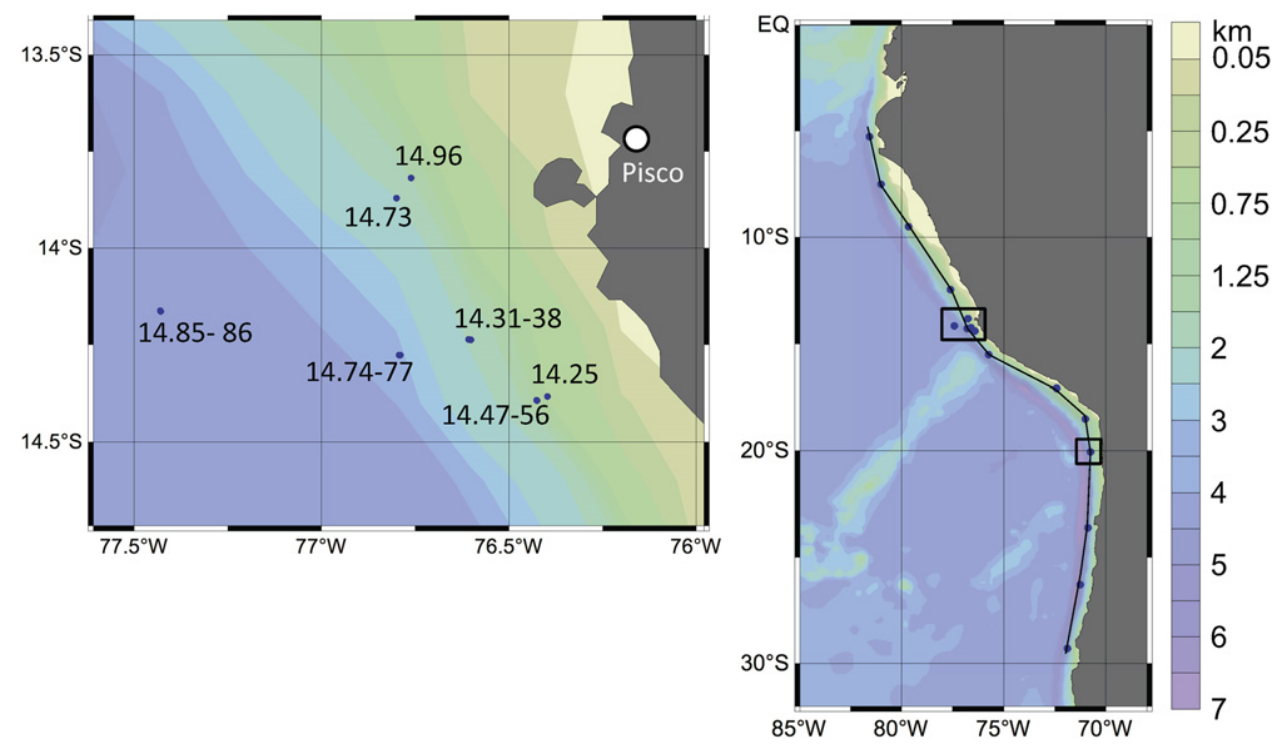

Fig. 1. Locations sampled along the coast of Peru and Chile. Oxygen was determined with highly sensitive STOX sensors at locations within the black rectangles. The map to the left shows the densely sampled area off Pisco with cast numbers. Locations along the black line were included in the transect in Fig. 2. 
Table 1

Positions and depths of hydrographic casts, availability of STOX oxygen data, and usage of SBE43 oxygen data.

\begin{tabular}{|c|c|c|c|c|c|c|}
\hline $\begin{array}{l}\text { Cast } \\
\text { ID }\end{array}$ & $\begin{array}{l}\text { Southern } \\
\text { latitude }\end{array}$ & $\begin{array}{l}\text { Western } \\
\text { longitude }\end{array}$ & $\begin{array}{l}\text { Bottom } \\
\text { depth, } \\
(\mathrm{m})\end{array}$ & $\begin{array}{l}\text { Cast } \\
\text { depth, } \\
(\mathrm{m})\end{array}$ & $\begin{array}{l}\text { STOX } \\
\text { data }\end{array}$ & SBE43 data ${ }^{a}$ \\
\hline 13.1 & $29^{\circ} 17.13$ & $071^{\circ} 52.98$ & 3646 & 500 & - & $>25 \mu \mathrm{mol} \mathrm{kg}{ }^{-1}$ \\
\hline 13.2 & $26^{\circ} 18.26$ & $071^{\circ} 15.74$ & 4740 & 501 & - & Corrected \\
\hline 14.1 & $23^{\circ} 37.36$ & $070^{\circ} 52.63$ & 3022 & 501 & - & Corrected \\
\hline 14.2 & $20^{\circ} 03.46$ & $070^{\circ} 45.27$ & 1480 & 200 & $++^{\mathrm{b}}$ & Not shown \\
\hline 14.6 & $20^{\circ} 03.47$ & $070^{\circ} 45.37$ & 1498 & 500 & - & Corrected \\
\hline 14.14 & $18^{\circ} 30.04$ & $071^{\circ} 00.13$ & 1203 & 499 & - & Corrected \\
\hline 14.17 & $17^{\circ} 05.14$ & $072^{\circ} 25.14$ & 1222 & 499 & - & Corrected \\
\hline 14.21 & $15^{\circ} 30.03$ & $075^{\circ} 44.74$ & 3135 & 500 & - & Corrected \\
\hline 14.25 & $14^{\circ} 22.92$ & $076^{\circ} 23.85$ & 313 & 301 & + & Not shown \\
\hline 14.31 & $14^{\circ} 14.19$ & $076^{\circ} 36.45$ & 998 & 501 & $+^{\mathrm{c}}$ & Zero calib. \\
\hline 14.32 & $14^{\circ} 14.22$ & $076^{\circ} 36.12$ & 980 & 500 & + & Not shown \\
\hline 14.38 & 1414.18 & $076^{\circ} 36.36$ & 1020 & 1014 & + & Not shown \\
\hline 14.47 & $14^{\circ} 23.52$ & $076^{\circ} 25.58$ & 393 & 382 & + & Zero calib. \\
\hline 14.56 & $14^{\circ} 23.57$ & $076^{\circ} 25.50$ & 388 & 152 & + & Not shown \\
\hline 14.73 & $13^{\circ} 52.23$ & $076^{\circ} 47.99$ & 736 & 400 & + & Zero calib. \\
\hline 14.74 & 1416.62 & $076^{\circ} 47.43$ & 2370 & 500 & + & Zero calib. \\
\hline 14.77 & $14^{\circ} 16.59$ & $076^{\circ} 47.60$ & 2426 & 500 & + & Zero calib. \\
\hline 14.85 & $14^{\circ} 09.79$ & $077^{\circ} 25.72$ & 5153 & 500 & + & Not shown \\
\hline 14.86 & $14^{\circ} 09.70$ & $077^{\circ} 25.79$ & 5155 & 500 & + & Not shown \\
\hline 14.96 & $13^{\circ} 49.08$ & $076^{\circ} 45.89$ & 617 & 508 & - & Corrected \\
\hline 14.100 & $12^{\circ} 26.62$ & $077^{\circ} 36.94$ & 583 & 502 & - & Corrected \\
\hline 14.121 & $09^{\circ} 29.84$ & $079^{\circ} 39.95$ & 843 & 500 & - & Corrected \\
\hline 14.122 & $07^{\circ} 30.01$ & $080^{\circ} 60.00$ & 2339 & 502 & - & Corrected \\
\hline 14.129 & $05^{\circ} 15.27$ & $081^{\circ} 34.68$ & 3016 & 416 & _- & $>3 \mu \mathrm{mol} \mathrm{kg}-1$ \\
\hline
\end{tabular}

a "Corrected": data corrected according to Eq. S1 and included in Fig. 1. "Not shown": data from stations outside the transect in Fig. 1. "Zero calib.": cast with simultaneous STOX and SBE43 oxygen determination used for zero calibration (Fig. S1). At stations 13.1 and 14.129 oxygen was not fully depleted and hence no zero correction was applied.

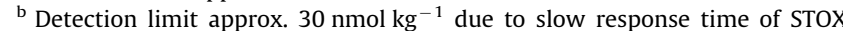
sensor.

c Results from 201 to 120 m depth were previously published by Revsbech et al. (2009).

upward casts were made at approx. $0.4 \mathrm{~m} \mathrm{~s}^{-1}$ interrupted by stops of $3 \mathrm{~min}$ or longer at specific depths. Thus, during stops, oxygen concentrations were determined from the average of typically three cycles of the STOX sensor, while concentrations determined during profiling represent data collected over $2 \mathrm{~m}$ with zero calibration performed $16 \mathrm{~m}$ below and $8 \mathrm{~m}$ above. STOX sensors were deployed successfully in 11 hydrographical casts off Peru around $14^{\circ} \mathrm{S}$ and once at $20^{\circ} \mathrm{S}$ off Chile. The detection limit for the Peru deployments was $10 \mathrm{nmol} \mathrm{kg}^{-1}$ estimated as 3 standard deviations of single-cycle oxygen determinations during stops within the OMZ core. In the deployment off Chile, the detection limit was $30 \mathrm{nmol} \mathrm{kg} \mathrm{kg}^{-1}$ due to a slow response time of the measuring circuit, which prevented the signal from stabilizing during the cycles of front-guard polarization.

Data from the SBE43 oxygen sensors was initially converted to oxygen concentrations by standard procedures using the coefficients for calibration and temperature and pressure correction determined by the manufacturer. The validity of the calibration in the normal concentration range was checked against Winkler titrations during the cruise and verified in the laboratory after the expedition, showing negligible drift. The data was filtered electronically with a $0.15 \mathrm{~s}$ low-pass filter and binned in $1 \mathrm{~s}$ time intervals. Comparison of the results from SBE43 sensors to those from the STOX sensor demonstrated characteristic reproducible responses of the SBE43 sensors in waters where oxygen was not detected by the STOX sensor, which allowed a recalibration of the SBE43 data, as described in Section 3.2.

Water for nitrite and nitrate analysis was collected in the Niskin bottles during the stops in the upward casts. The bottles were closed at the end of each stop. Nitrite was analyzed spectrophotometrically (detection limit $0.1 \mu \mathrm{mol} \mathrm{L}{ }^{-1}$, typical S.D. $0.05 \mu \mathrm{mol} \mathrm{L}^{-1}$; Grasshoff, 1983) and nitrate+nitrite was analyzed by NO chemiluminescence after reduction with $\mathrm{V}^{3+}$ (relative S.D. 5\%; Braman and Hendrix, 1989). Isopleths were plotted using Ocean Data View v. 4.3.6 (Schlitzer, 2010).

\section{Results and discussion}

\subsection{General oceanographic conditions}

The measurements were made 2-3 months after a weak el Niño event that peaked in November 2006, and the oceanographic conditions in the ETSP had just returned to the normal range as indicated by the Oceanic Niño Index (NWS Climate Prediction Center). Sea surface temperatures along the cruise track were at or slightly $\left(<1{ }^{\circ} \mathrm{C}\right)$ above the normal for February (NASA Earth Observations), and the distribution and concentrations of chlorophyll as estimated from satellite closely resembled the monthly climatology for the past decade (OceanColor Web).

The depthwise and meridional distributions of salinity and temperature (Fig. 2) were also similar to previous reports (Silva et al., 2009 and refs. therein). Thus, as described by Silva et al. (2009), Equatorial Subsurface Water (ESSW) dominated the upper $500 \mathrm{~m}$, with its salinity core (34.9) shoaling from $>200 \mathrm{~m}$ at $5^{\circ} \mathrm{S}$ to $\sim 100 \mathrm{~m}$ at $15-20^{\circ} \mathrm{S}$, south of which it was eroded, such that at $28^{\circ} \mathrm{S}$ a maximum salinity of 34.6 was reached at $200 \mathrm{~m}$. Below the ESSW core, salinity gradually decreased towards a minimum of 34.55 reached at 700-900 m depth (not shown), which represents the much eroded northern extension of the Antarctic Intermediate Water (AAIW). Along the northern and central Peruvian coast the ESSW was directly overlain by more saline Subtropical Water (STW; core characteristics: $\geq 20^{\circ} \mathrm{C}, S=35.2$ ) whereas south of $15^{\circ} \mathrm{S}$ a shallow salinity minimum of $\leq 34.8$ was present between the ESSW and the STW as previously described (Silva et al., 2009 and refs. therein). This minimum, which was as shallow as $30 \mathrm{~m}$ at $17-20^{\circ} \mathrm{S}$, is attributed to a tongue of Subantarctic Water (SAAW) often referred to as Eastern South Pacific Intermediate Water (ESPIW; Schneider et al., 2003; Silva et al., 2009).

\subsection{Oxygen in the $\mathrm{OMZ}$}

Oxygen was consistently below the detection limit of the STOX sensors throughout the approximately $200 \mathrm{~m}$-thick OMZ core in 10 out of 12 profiles, including nine recorded $20-55 \mathrm{~km}$ off the Peruvian coast around $14^{\circ} \mathrm{S}$ as well as the one from $20^{\circ} \mathrm{S}$ off Chile (Fig. 3(a)). Complete oxygen depletion coincided with densities $\left(\sigma_{\theta}\right)$ of $26.1-26.7 \mathrm{~kg} \mathrm{~m}^{-3}\left(T=10-14{ }^{\circ} \mathrm{C} ; S=34.7-34.9\right)$, respectively. By contrast, $10-50 \mathrm{nmol} \mathrm{kg}{ }^{-1}$ oxygen was detected through most of the OMZ core in two casts at a station $120 \mathrm{~km}$ off the coast of Peru (Fig. 3(b); casts 14.85 and 14.86). There was a good agreement between oxygen determinations from coinciding depths from these two casts, which were separated by an interval of $2 \mathrm{~h}$. Thus, oxygen in both profiles increased from $\leq 10 \mathrm{nmol} \mathrm{kg}^{-1}$ in single determinations at $\sim 300 \mathrm{~m}$ to $>40 \mathrm{nmol} \mathrm{kg}^{-1}$ at $250 \mathrm{~m}$, decreasing again to $10 \mathrm{nmol} \mathrm{kg}{ }^{-1}$ at $180 \mathrm{~m}$. Both profiles also showed a peak with up to $400 \mathrm{nmol} \mathrm{kg}^{-1}$ between 50 and $80 \mathrm{~m}$ depth. The salinity-temperature relationship showed disturbances in the stratification at the depths where oxygen was detected (Fig. 4). This was seen as two intrusions of less saline water at $11.0-12.3^{\circ} \mathrm{C}$ and above $12.7{ }^{\circ} \mathrm{C}$, respectively, relative to the mixing line between Equatorial Subsurface Water and Antarctic Intermediate Water, while the S-T relationship followed this line more closely at most other stations. The deeper intrusion extended to densities of $26.60-26.62 \mathrm{~kg} \mathrm{~m}^{-3}$ corresponding to depths of $275-280 \mathrm{~m}$, while no disturbance was observed at $300 \mathrm{~m}$, consistent with the lack of detectable oxygen at 


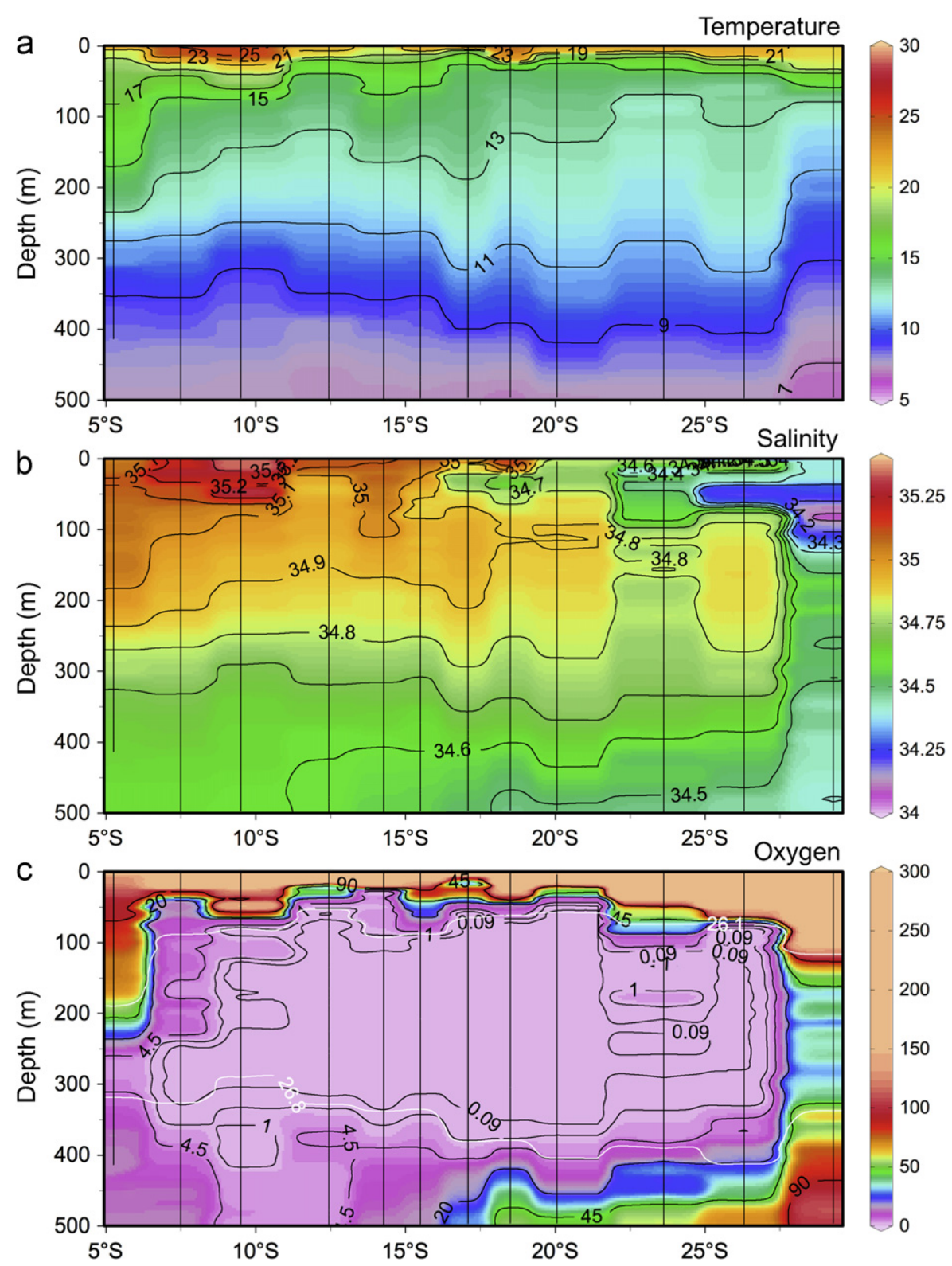

Fig. 2. Distribution of temperature $\left({ }^{\circ} \mathrm{C}\right)$, salinity (psu), and oxygen $\left(\mu \mathrm{mol} \mathrm{kg}{ }^{-1}\right.$ ) based on corrected data from the SBE43 sensor, along the west coast of South America in February 2007 (transect in Fig. 1). Vertical lines indicate sampling locations. For oxygen, isopleths are plotted in black for the detection limit of 90 nmol kg ${ }^{-1}$ and for thresholds previously used to define oxygen minimum zones. Isopycnals for the densities $\left(\sigma_{\theta}\right) 26.1$ and $26.8 \mathrm{~kg} \mathrm{~m}^{-3}$ are plotted in white.

this depth (Figs. $3 \mathrm{~b}$ and 4). The oxygen minimum at $180 \mathrm{~m}$ coincided with the water layer that separated the two intrusions, which further substantiated the link between the presence of oxygen and the intrusions. While a salinity minimum originating from SAAW/ESPIW is occasionally present above $12^{\circ} \mathrm{C}$, the deeper intrusion to $11^{\circ} \mathrm{C}$ seems atypical in this region (e.g., Huyer et al., 1978; Copin-Montegut and Raimbault, 1994). Thus, the deep penetration of nanomolar oxygen levels was likely a transient phenomenon, although the possibility that it represented a more general inshore-offshore trend in oxygen levels cannot be completely ruled out without measurements further off shore.

At the stations off Peru, the upper boundary of complete oxygen depletion was located at 100-120 m depth (Fig. 3(a)). In most of the casts, oxygen remained below $3 \mu \mathrm{mol} \mathrm{kg}{ }^{-1}$ upwards from this boundary to 30-60 m depth, with higher concentrations in the deeper part of the low-oxygen zone and a secondary minimum near its upper boundary. Concentrations in this shallow minimum were generally below $1 \mu \mathrm{mol} \mathrm{kg}{ }^{-1}$, and in two casts
(14.31 and 14.73) complete oxygen depletion was detected at 60 and $30 \mathrm{~m}$ depth, respectively, corresponding to densities of $25.91-25.94 \mathrm{~kg} \mathrm{~m}^{-3}$. Due to the discrete mode of STOX sensor measurements, oxygen-depleted layers of few meters thickness would only be detected with certainty if they coincided with stops in the CTD cast. Thus, similar oxygen depleted layers could easily have been missed in other casts.

Simultaneous deployment of STOX and conventional SBE43 oxygen sensors allowed accurate zero-point calibration of the conventional sensors and thereby the extension of our analysis to the entire cruise track, as well as an evaluation of the continuity of oxygen levels at depths between the STOX measurements. The SBE43 sensors exhibited a characteristic slow asymptotic decrease in signal in the core of the OMZ where oxygen was not detected by the STOX sensor (Fig. 5(a), (b) and Fig. 6). The decrease in signal was independent of whether the instrument was profiling or stopped at a given depth, and the response was highly reproducible for each sensor for casts to 400-500 m depth. 
a
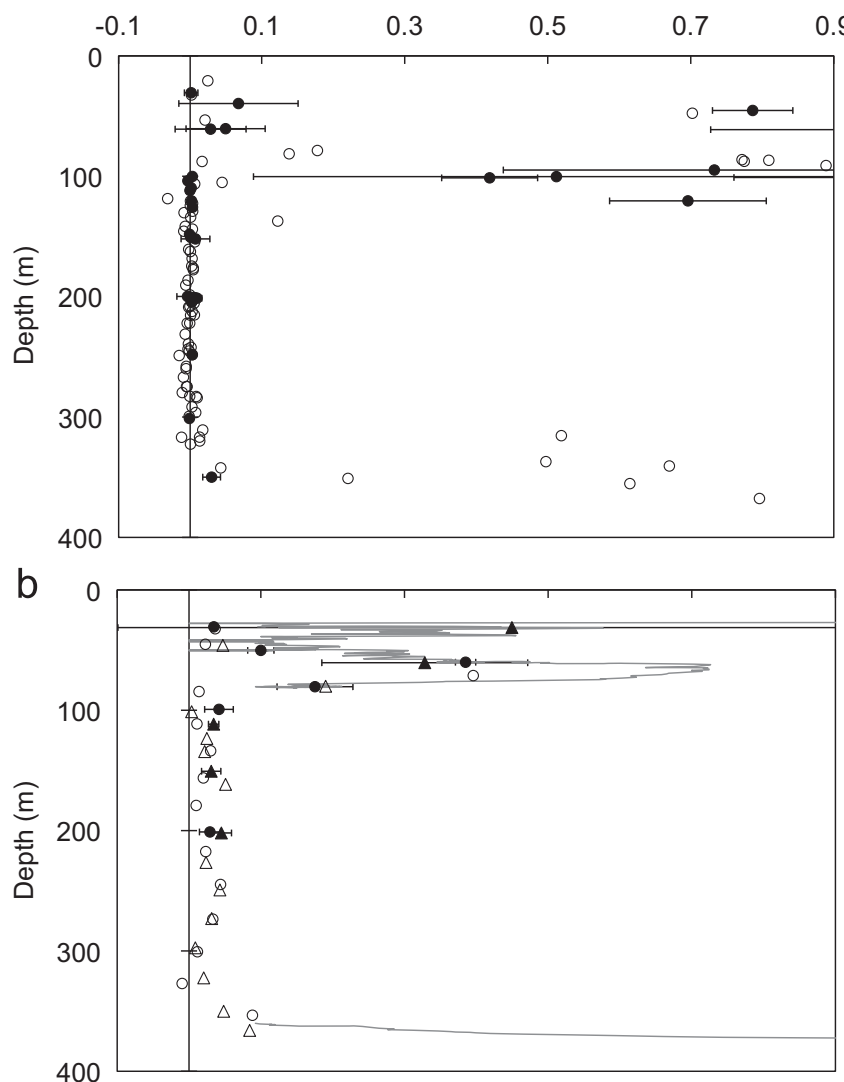

Fig. 3. Depth distributions of oxygen through the core of the oxygen minimum zone off Peru as determined in situ with STOX oxygen sensors. Filled symbols represent measurements at fixed depth with standard deviation of replicates $(n=3-4)$ while open symbols represent measurements recorded during profiling. (a) Results from eight casts no. 14.10-14.77. (b) Results from two casts (14.85, triangles, 14.86, circles) from the location furthest off shore (Fig. 1), with corrected oxygen concentrations from the SBE43 sensor from cast 14.85 shown as a grey line with measurements below the detection limit of $0.09 \mu \mathrm{mol} \mathrm{kg}^{-1}$ omitted for clarity. The large error bars associated with stationary measurements above $125 \mathrm{~m}$ depth reflect temporal fluctuations in the oxygen concentration during the measurement in the steep oxycline.

We attribute the time-dependent signal to oxygen released from the plastics of the SBE43 sensors and the flow-through system in which they are mounted. The drift was strongest during the downward cast (see Revsbech et al., 2011). For further analysis, we therefore used data from the upward casts, where the drift typically amounted to $0.5 \mu \mathrm{mol} \mathrm{kg}{ }^{-1}$ during the passage through the OMZ core. The readings from the two SBE43 sensors agreed within $0.1 \mu \mathrm{mol} \mathrm{kg}^{-1}$ in the oxygen-depleted core (data not shown), and data from one sensor was used for further calculations. An ad hoc zero correction of the SBE43 oxygen data was derived by fitting the empirical time-dependent asymptotic function $C(t)=a e^{-b(t-t 0)}+c$ to the uncorrected SBE43 oxygen reading during the passage of the oxygen depleted zone, with $t_{0}$ representing the time of entrance to the oxygen-depleted core (Fig. 5(c)). When the CTD first entered the oxygen-depleted core from below the SBE43 sensor had an oxygen reading of $1.7 \mu \mathrm{mol} \mathrm{kg}^{-1}$ and $t_{0}$ was thus defined as the time when the SBE43 reading decreased below this value. In cast 14.47 , for example, the deepest depth where oxygen was undetectable with the STOX sensor was $296 \mathrm{~m}$ and the SBE43 reading here was $1.7 \mu \mathrm{mol} \mathrm{L}^{-1}$ (Fig. 5(a)). The reading decreased below $1.7 \mu \mathrm{mol} \mathrm{L}^{-1}$ at an aquisition time of $1616 \mathrm{~s}$ (Fig. 5(b)), which was consequently defined as $t_{0}$ (Fig. $5(\mathrm{c})$ ). Data from five casts

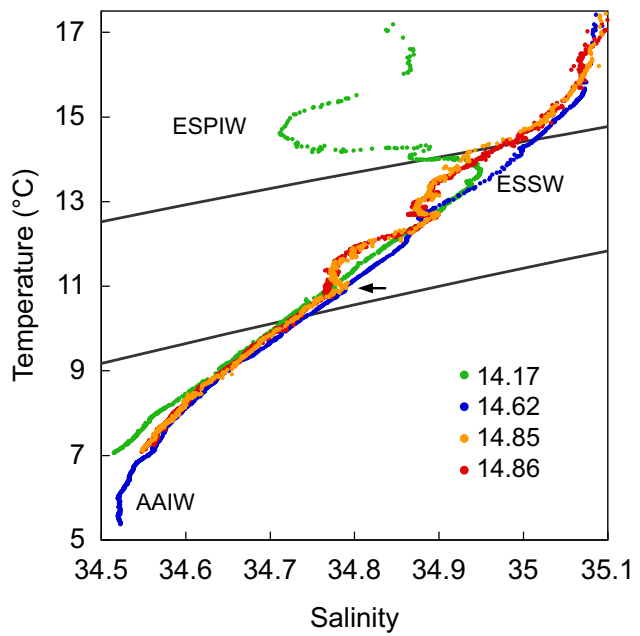

Fig. 4. Salinity-temperature diagrams for casts 14.85 and 14.86 at a position $120 \mathrm{~km}$ off shore, compared to typical values from other stations, exemplified by casts 14.17 and 14.62 with and without the presence of Eastern South Pacific Intermediate Water (ESPIW), respectively. The typical linear relationship between temperature and salinity at $7-13^{\circ} \mathrm{C}$ in casts 14.17 and 14.62 represents the transition between Antarctic Intermediate Water (AAIW; $T=5^{\circ} \mathrm{C}$ ) and Equatorial Subsurface Water (ESSW; $T=13^{\circ} \mathrm{C}$ ). The grey lines indicate specific densities $\left(\sigma_{\theta}\right)$ of 26.1 and $26.7 \mathrm{~kg} \mathrm{~m}^{-3}$ between which the OMZ core is located. The deviation of the T-S relationship from the linear relationship in casts 14.85 and 14.86 indicates intrusions, which reached a depth of $280 \mathrm{~m}$ indicated by the arrow, and coincided with the detection of $10-50 \mathrm{nmol} \mathrm{kg}^{-1}$ of oxygen (Fig. 3(b)).

were used for a non-linear least-squares fit of the function, yielding the parameters $a=0.598 \mu \mathrm{mol} \mathrm{kg}^{-1}, \quad b=0.00148 \mathrm{~s}^{-1}$, $c=1.08 \mu \mathrm{mol} \mathrm{kg}^{-1}$. The SBE43 oxygen data were corrected by subtraction of the parameterized function from the uncorrected reading (Fig. 6):

$\mathrm{O}_{2}$ SBE43 corrected $=\mathrm{O}_{2}$ SBE43 uncorrected $-a e^{-b(t-t 0)}-c$

The detection limit of $\mathrm{O}_{2}$ SBE43 corrected was $0.09 \mu \mathrm{mol} \mathrm{kg}^{-1}$ estimated as 3 times the standard deviation of $0.029 \mu \mathrm{mol} \mathrm{kg}^{-1}$ of the values obtained in the $\mathrm{OMZ}$ core where oxygen was not detectable with STOX sensors (Table 2).

The corrected SBE43 data revealed a contiguous, 200-300-m deep zone with no detectable oxygen along $1180 \mathrm{~km}$ of the transect between $12.5^{\circ}$ and $20^{\circ} \mathrm{S}$ (Fig. 2(c)). Complete oxygen depletion was also found north and south of this section, from $7.5^{\circ}$ to $26.5^{\circ}$ S, covering $2500 \mathrm{~km}$ of the transect, but here it was restricted to thinner layers bordered by intrusions containing 0.2 to $3.2 \mu \mathrm{mol} \mathrm{kg}^{-1}$ oxygen. There was a good agreement between corrected SBE43 data and STOX data in the low-oxygen layer overlying the $\mathrm{OMZ}$ core (example from cast 14.85 in Fig. 3(b)), which confirmed the ability of the SBE43 sensor to resolve submicromolar concentrations after proper zero calibration, and further revealed the complicated structure of oxygen distributions in this layer. The oxygen-depleted water mass grew in thickness from $\sim 200 \mathrm{~m}$ at latitudes north of $15^{\circ} \mathrm{S}$ to $300 \mathrm{~m}$ at $20^{\circ} \mathrm{S}$, corresponding to densities $\left(\sigma_{\theta}\right)$ of $26.15-26.8 \mathrm{~kg} \mathrm{~m}^{-3}$ and 26.10-26.7, respectively (Fig. 2(c)). It corresponded closely to the core of the ESSW, being restricted downwards, towards the AAIW, and to the South to salinities above 34.75, while the upper limit was at 34.95 towards the STW and at 34.80 in the presence of the ESPIW (Figs. 2(b) and (c), 4).

Both the horizontal and vertical extent of oxygen depletion agree well with previous descriptions of the distribution of waters with oxygen at or below the detection limit in the inner part of the South Pacific OMZ (e.g., Wooster and Gilmartin, 1961; Zuta and Guillen, 1970; Codispoti and Packard, 1980; Silva et al., 2009). However, our measurements tighten the constraints on oxygen in 

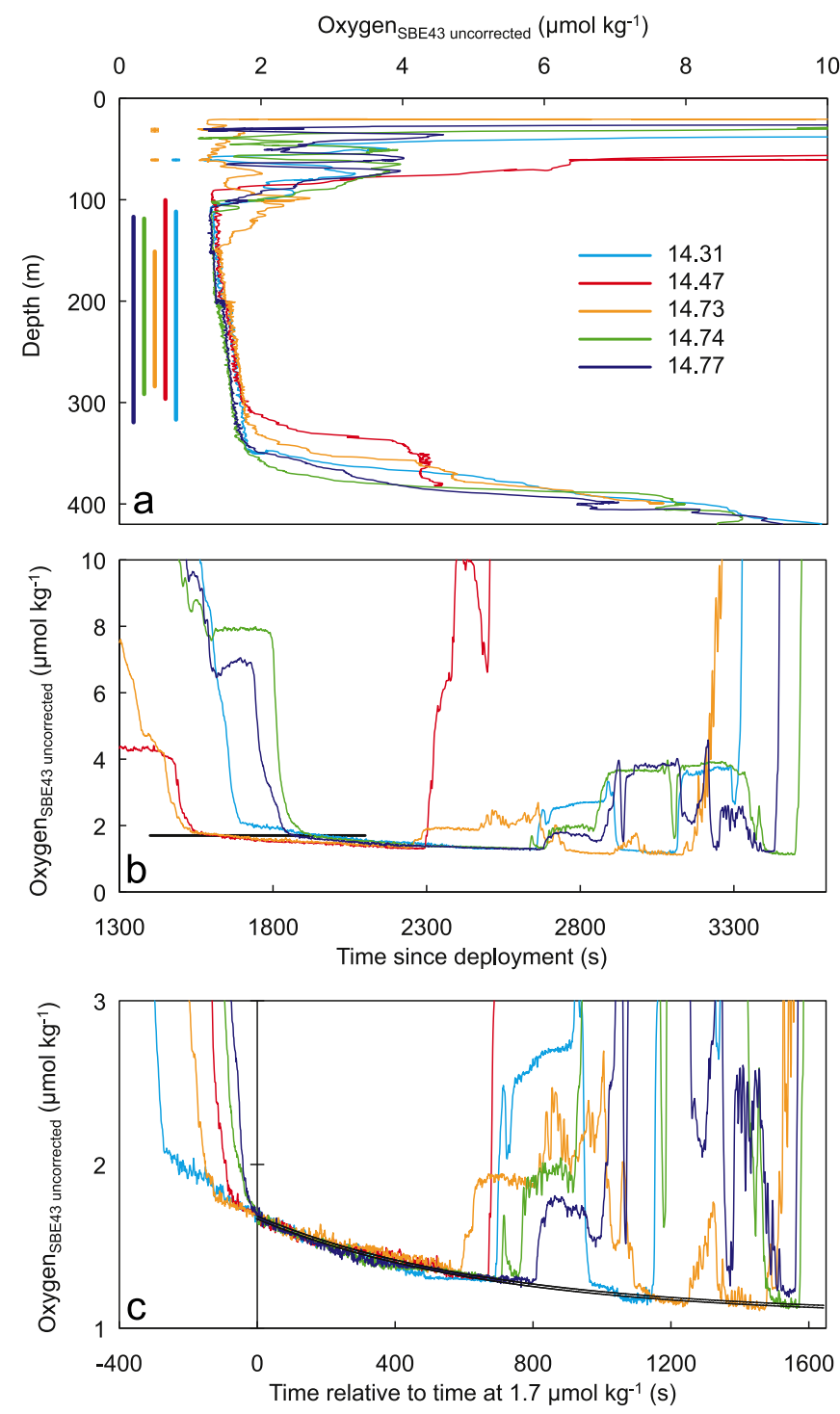

Fig. 5. Zero calibration of SBE43 oxygen data. SBE43 oxygen data from stations where the STOX oxygen sensor demonstrated complete oxygen depletion in the OMZ core. (a) Profiles of uncorrected oxygen readings from the SBE43 sensor $\left(\mathrm{O}_{2}\right.$ SBE43 uncorrected) from five casts through the OMZ core, as recorded during the upward cast. Thick vertical lines to the left indicate the depth intervals where oxygen was depleted below the detection limit of the STOX sensor. In casts 14.31 and 14.73, thin secondary oxygen depleted layers were detected above the OMZ core around 30 and $60 \mathrm{~m}$ depth as indicated by short horizontal lines. (b) Same data as in (a) plotted as function of deployment time. The horizontal black line indicates the threshold of $1.7 \mu \mathrm{mol} \mathrm{kg}^{-1}$ in $\mathrm{O}_{2}$ SBE43 uncorrected, which corresponds to the onset of anoxia as demonstrated by STOX oxygen data. (c) Same data as in (b) plotted as function of time relative to the time when $\mathrm{O}_{2}$ SBE43 uncorrected dropped below $1.7 \mu \mathrm{mol} \mathrm{kg}-1$. The double line represents the least-sum-of-squares fit of the function $a e^{-b(t-t 0)}+c$ to the data (see text for details).

the core of the OMZ by two to three orders of magnitude relative to the previous reports that constrained oxygen to less than 1-5 $(-10) \mu \mathrm{mol} \mathrm{kg}{ }^{-1}$ depending on the analytical sensitivity. The geographic extent of oxygen depletion (Fig. 2(c)) and its tight association with the ESSW under normal hydrographical conditions, indicate that oxygen depletion to $<0.09 \mu \mathrm{mol} \mathrm{kg}{ }^{-1}$ is a normal phenomenon in the Eastern South Pacific OMZ. The ESSW is transported southward by the Peru-Chile Undercurrent at core velocities of $5-10 \mathrm{~cm} \mathrm{~s}^{-1}$ (Wooster and Gilmartin, 1961; Fonseca, 1989; Czeschel et al., 2011) corresponding to 4-9 months for the $1180 \mathrm{~km}$ distance with full oxygen depletion (see Codispoti and Christensen, 1985, for a similar estimate of residence time). Considering a residence time of the ESSW
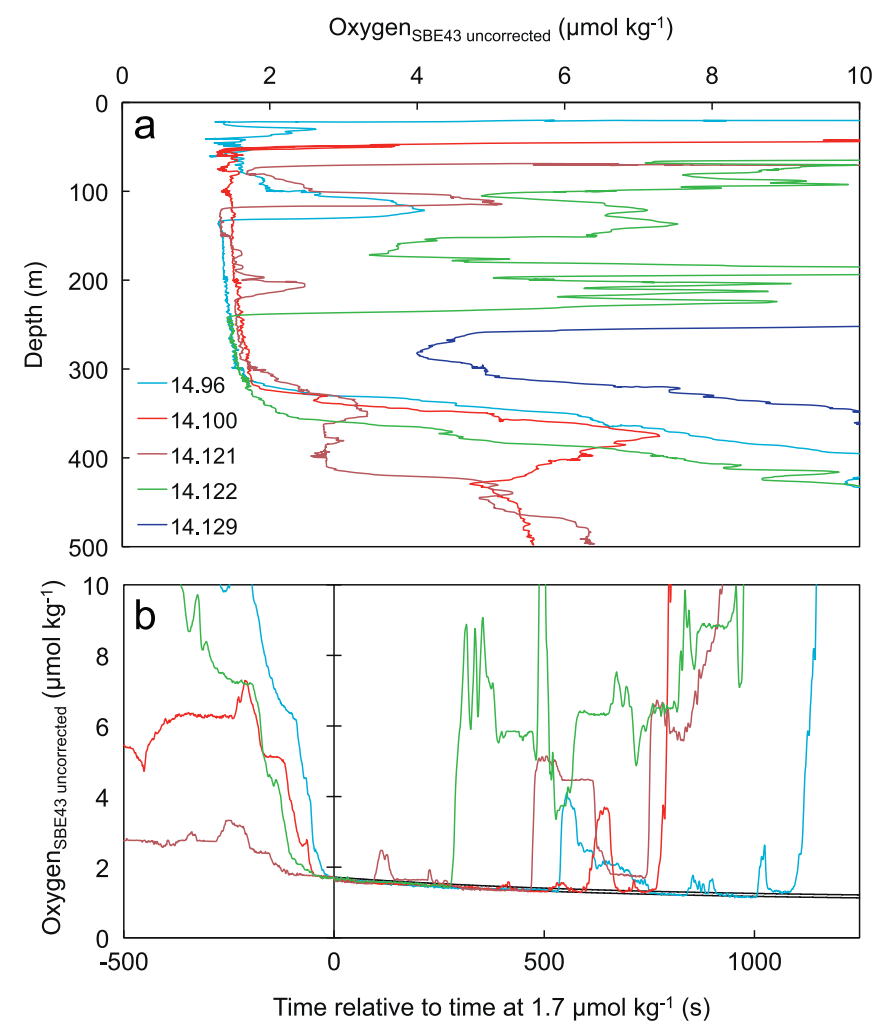

Fig. 6. Examples of zero correction of oxygen data from the SBE43 sensor from casts where STOX sensor data were not available. (a) Profiles of uncorrected readings through the OMZ core from upward casts. (b) Same data plotted as a function of time relative to the time when the $\mathrm{O}_{2}$ SBE43 uncorrected dropped below $1.7 \mu \mathrm{mol} \mathrm{kg}{ }^{-1}$. The double line represents the zero correction derived from simultaneous STOX and SBE43 oxygen determinations in other casts (Fig. 5).

of several months as well as the relatively weak seasonality in oxygen distributions in the ESP OMZ (Paulmier and Ruiz-Pino, 2009), our oxygen measurements may indeed represent typical conditions in the inner part of the Eastern South Pacific OMZ. For the southern part of the OMZ, this is supported by further oxygen determinations with STOX sensors at $20^{\circ} \mathrm{S}$ (close to our cast 14.6), which found oxygen to be undetectable in several casts in both August 2009 and January 2010 (Canfield et al., 2010; unpubl. results).

The stations with oxygen depletion were located $22-130 \mathrm{~km}$ from shore, and should thus be representative of the $175 \mathrm{~km}$ wide inner zone of the South Pacific OMZ that was previously estimated to house $76 \%$ of its denitrification (Codispoti and Packard, 1980). Under the conservative assumption that they are representative of a zone of at least $50 \mathrm{~km}$ width, we estimate a total volume of oxygen-depleted water $\left(<0.09 \mu \mathrm{mol} \mathrm{kg}^{-1}\right)$ of at least $2.4 \times 10^{13} \mathrm{~m}^{3}$, based on the $480 \mathrm{~km}^{2}$ cross section held within the $0.09 \mu \mathrm{mol} \mathrm{kg}{ }^{-1}$ isopleth along the transect (Fig. 2(c)). The cross section was determined graphically by plotting the isopleth with distance rather than latitude on the $x$ axis. This volume is 24 times larger than the most recent estimate of suboxic $\left(<4.5 \mu \mathrm{mol} \mathrm{kg}^{-1}\right)$ water in the Eastern South Pacific (Karstensen et al., 2008). The volume corresponding to the $1180 \mathrm{~km}$ of the transect with massive oxygen depletion (average core thickness $250 \mathrm{~m}$ ) was $1.5 \times 10^{13} \mathrm{~m}^{3}$, which is still 15 times higher than the previous estimate. Thus, oxygen depletion was not only much more severe than previously known; extreme depletion also affected a far greater volume than previously documented. We attribute this difference primarily to the improved sensitivity of the oxygen analysis. Our strategy of sampling along the coast may also have contributed, since this region is poorly represented in some ocean databases. 
Table 2

Summary of corrected SBE43 oxygen data from oxygen-depleted waters.

\begin{tabular}{|c|c|c|c|c|}
\hline Cast ID & $\begin{array}{l}\text { Depth } \\
\text { interval, } \\
(\mathrm{M})^{\mathrm{a}}\end{array}$ & $\begin{array}{l}\text { Acquisition } \\
\text { duration, } \\
\mathrm{s}^{\mathrm{b}}\end{array}$ & $\begin{array}{l}\text { Mean } \\
\text { concentration }{ }^{\mathrm{c}} \text {, } \\
\mu \mathrm{mol} \mathrm{kg}{ }^{-1}\end{array}$ & $\begin{array}{l}\text { Standard } \\
\text { deviation, } \\
\mu \mathrm{mol} \mathrm{kg}^{-1}\end{array}$ \\
\hline \multicolumn{5}{|c|}{ Casts for zero calibration with STOX data: } \\
\hline 14.31 & $111-288$ & 720 & -0.015 & 0.025 \\
\hline 14.47 & $91-282$ & 654 & 0.011 & 0.024 \\
\hline 14.73 & $149-265$ & 756 & 0.025 & 0.029 \\
\hline 14.74 & $101-335$ & 709 & -0.010 & 0.023 \\
\hline 14.77 & $112-328$ & 713 & -0.012 & 0.020 \\
\hline All data $14.31-14.77$ & & 3552 & 0.000 & 0.029 \\
\hline \multicolumn{5}{|c|}{ Casts without STOX data: } \\
\hline 14.6 & $50-347$ & 1104 & -0.020 & 0.020 \\
\hline 14.14 & $70-291$ & 588 & 0.002 & 0.021 \\
\hline 14.17 & $58-293$ & 699 & 0.019 & 0.022 \\
\hline 14.21 & $96-293$ & 486 & -0.012 & 0.034 \\
\hline 14.96 & $134-315$ & 534 & -0.030 & 0.024 \\
\hline 14.100 & $55-279$ & 395 & -0.026 & 0.023 \\
\hline 14.122 & $242-317$ & 290 & -0.006 & 0.023 \\
\hline All data $14.6-14.122$ & & 4092 & -0.010 & 0.029 \\
\hline
\end{tabular}

${ }^{a}$ Depth interval with oxygen depletion used for calculation. For casts with STOX oxygen data, the interval corresponds to the depths where oxygen was not detected with the STOX sensor. For casts without STOX oxygen data, the lower boundary was taken as the depth where the uncorrected SBE43 oxygen reading decreased below $1.7 \mu \mathrm{mol} \mathrm{kg}^{-1}$ during the upcast (corresponding to $t_{0}$ in Eq. (1)), and the upper boundary was defined as the first subsequent depth where the corrected SBE43 oxygen reading increased above $50 \mathrm{nmol} \mathrm{kg}^{-1}$

${ }^{b}$ Duration of data acquisition within the depth range defined in the preceding column.

${ }^{\mathrm{c}}$ Corrected concentrations were derived by subtraction of a time-dependent zero-correction, which necessarily results in slightly negative means for some casts.

\subsection{Respiration in the $\mathrm{OMZ}$}

The widespread depletion of oxygen to nanomolar concentrations or lower indicates that oxygen is efficiently respired to these low levels by the microbial community, while metazoan respiration must be strongly inhibited, even in those low-oxygen-adapted animals that are found in OMZs (Seibel, 2011). The case for active microbial respiration is supported by the apparent half-saturation coefficient for oxygen respiration of less than $0.02 \mu \mathrm{mol} \mathrm{kg}^{-1}$ reported for water from the Peruvian OMZ (Revsbech et al., 2009). Such kinetics imply the involvement of specialized respiratory oxidases with high oxygen affinity $\left(K_{m}<0.01 \mu \mathrm{mol} \mathrm{kg}^{-1}\right)$ as found in a variety of bacteria (Contreras et al., 1999). If oxygen consumption follows Michaelis-Menten kinetics, the time $t$ to reach a given concentration $C$ from an initial concentration $C_{0}$ can be calculated as $t=\left(C_{0}-C+K_{m} \ln \left[C_{0} / C\right]\right) V_{\max }^{-1}$ (Dalsgaard and Bak, 1994). With a half saturation coefficient of $0.02 \mu \mathrm{mol} \mathrm{kg}^{-1}$ and typical mesopelagic rates of non-oxygen limited oxygen respiration $\left(V_{\max }\right)$ of $0.02-$ $0.05 \mu \mathrm{mol} \mathrm{kg} \mathrm{kg}^{-1} \mathrm{~d}^{-1}$ (Aristegui et al., 2005), oxygen would be depleted from the detection limit of the conventional sensor of $0.09 \mu \mathrm{mol} \mathrm{kg}{ }^{-1}$ to $0.01 \mu \mathrm{mol} \mathrm{kg}{ }^{-1}$ within 2-6 days and to $0.001 \mu \mathrm{mol} \mathrm{kg}{ }^{-1}$ in 3-8 days, which is short relative to the residence time of the ESSW (Section 3.2). This is a conservative estimate because respiration rates in the region are likely above average for mesopelagic waters due to the high productivity. Thus, while mixing-events or intrusions may occasionally introduce oxygen into the $\mathrm{OMZ}$ core, as indicated by our finding of $10-50 \mathrm{nmol} \mathrm{kg}^{-1}$ oxygen at one station off Peru (Fig. 3(b)), it is not likely that oxygen persists at concentrations between the detection limits of the two methods used here $\left(0.01-0.09 \mu \mathrm{mol} \mathrm{kg}{ }^{-1}\right)$, but rather that it is depleted to the limit of microbial respiration, which is probably in the picomolar range or lower.
A tight coupling is expected between the oxygen dependence of aerobic respiration and the onset of dissimilatory nitrate reduction, the first step in anaerobic respiration with nitrogen compounds (Devol, 1978). During our sampling, nitrate was present at concentrations greater than $10 \mu \mathrm{mol} \mathrm{kg}{ }^{-1}$ throughout the OMZ while nitrite accumulated to micromolar levels in the OMZ core, in accordance with previous observations (Wooster et al., 1965; Fiadeiro and Strickland, 1968; Silva et al., 2009), with maximum concentrations increasing from north to south and reaching $10 \mu \mathrm{mol} \mathrm{kg}^{-1}$ at $20^{\circ} \mathrm{S}$. We only observed the accumulation of nitrite above $0.5 \mu \mathrm{mol} \mathrm{kg}{ }^{-1}$ when oxygen was undetectable with the SBE43 sensor, and at oxygen concentrations less than $0.05 \mu \mathrm{mol} \mathrm{kg}{ }^{-1}$ where STOX sensor data were available (Fig. 7). This oxygen threshold for the secondary nitrite maximum is one to two orders of magnitude lower than thresholds of 1$4.5 \mu \mathrm{mol} \mathrm{kg}{ }^{-1}$ previously estimated in large OMZ surveys with the same approach (Cline and Richards, 1972; Codispoti and Christensen, 1985; Morrison et al., 1999). The difference can be attributed to the improved sensitivity of oxygen determination since those studies placed the threshold of nitrite accumulation near the detection limit of their oxygen analysis. Although the mutual exclusion of oxygen and the secondary nitrite maximum in the OMZ reflects only the net outcome of interactions between aerobic and anaerobic processes, it has important implications for the interactions of oxygen and nitrogen transformations. It confirms that nitrate reduction rather than ammonium oxidation is the source of the secondary nitrite maximum, because the buildup of nitrite occurs in the absence of oxygen, both along the vertical gradients and along the path of the ESSW. The relationship between oxygen and nitrite also implies that nitrite oxidation is highly efficient at nanomolar oxygen concentrations, consuming any nitrite formed from ammonium oxidation or mixed in from the adjacent OMZ core. This is consistent with direct observations of nitrite oxidation in incubations of $\mathrm{OMZ}$ water at very low oxygen concentrations (Lipschultz et al., 1990; Füssel et al., in press). In principle, other nitrite-consuming processes such as denitrification and anammox could also be active at low oxygen levels (Farías et al., 2009; Jensen et al., 2008), but they are less likely to explain the disappearance of nitrite

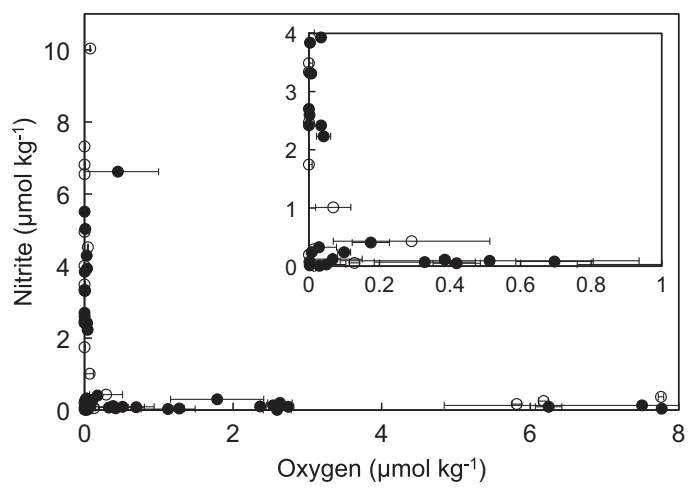

Fig. 7. Relative distribution of oxygen and nitrite in the core and oxycline of the oxygen minimum zone. Filled circles represent oxygen concentrations determined with STOX oxygen sensors with standard deviation of replicates $(n=3-4)$ and open circles represent concentrations from a conventional sensor after recalibration. Oxygen was measured in situ at fixed depth while the water samplers were allowed to equilibrate with the surrounding water. Nitrite concentrations greater than $0.5 \mu \mathrm{mol} \mathrm{kg} \mathrm{kg}^{-1}$ were only found at oxygen concentrations below $0.05 \mu \mathrm{mol} \mathrm{kg}{ }^{-1}$ except for one sample containing $6.6 \mu \mathrm{mol} \mathrm{kg}{ }^{-1}$ nitrite at $0.4 \pm 0.5 \mu \mathrm{mol} \mathrm{kg}^{-1}$ oxygen. In this case, sampled at $30 \mathrm{~m}$ depth, oxygen fluctuated rapidly from below 0.05 to above $1 \mu \mathrm{mol} \mathrm{kg}{ }^{-1}$ due to water movement, and fluctuations were likely too fast to equilibrate with water inside the water sampler. 
with the appearance of oxygen, as they appear more sensitive to oxygen than the nitrite-producing pathways (Kalvelage et al., 2011). Mixing events must occasionally bring higher concentrations of oxygen and nitrite together, but such events were too rare to be caught in our survey. This further implies that elevated nitrite levels are a good indicator of complete oxygen depletion in the OMZ, and thus, that the volume of oxygen-depleted water in the Eastern South Pacific $\left(<0.09 \mu \mathrm{mol} \mathrm{kg}{ }^{-1}\right)$ may be as large as $2 \times 10^{14} \mathrm{~m}^{3}$, the volume occupied by the secondary nitrite maximum (Paulmier and Ruiz-Pino, 2009), which is eight times the $2.4 \times 10^{13} \mathrm{~m}^{3}$ estimated above.

The high efficiency of oxygen respiration at oxygen concentrations in the low nanomolar range inferred here, suggests that aerobes would efficiently outcompete anaerobic nitrogen metabolisms under steady state conditions in this oxygen range (see also discussion by Codispoti et al., 2005). Since both denitrification and anammox utilize nitrite, and since $\mathrm{N}_{2}$ production in the Eastern South Pacific OMZ has only been detected experimentally at nitrite concentrations greater than $0.5 \mu \mathrm{mol} \mathrm{kg}{ }^{-1}$ (Thamdrup et al., 2006, Lam et al., 2009), the relative distribution of oxygen and nitrite (Fig. 7) further suggests that $\mathrm{N}_{2}$ production in this system may be restricted to fully oxygen-depleted waters or water with a recent history of anoxia. This, however, needs verification from detailed investigations of the effect of nanomolar oxygen on individual nitrogen-transforming processes and their interactions.

\section{Conclusions and perspectives}

Our results define sharp limits to the influence of oxygen on biological and biogeochemical processes in the Eastern South Pacific OMZ. The absence of detectable oxygen in the OMZ core along more than $1000 \mathrm{~km}$ of our cruise track indicates that a large volume of the OMZ core is functionally anoxic through extended periods of time. It is not possible to demonstrate anoxia, the absence of oxygen, directly because any oxygen assay will have some detection limit, but with oxygen depleted to low nanomolar or even picomolar levels, and given a residence time of several months for the water in the OMZ core, oxygen cannot be of sustained significance in biological metabolisms or other major biogeochemical processes, which justifies our definition of the core as being functionally anoxic. Because anoxia cannot be proven directly, and given the relatively high detection limits of conventional oxygen assays, the accumulation of hydrogen sulfide has previously been used as an indicator of anoxic conditions (Richards, 1965). Hydrogen sulfide is only rarely detected in pelagic OMZs but this appears to be due to efficient oxidation coupled to nitrate or nitrite reduction, rather than to the lack of production, as active sulfate reduction has been detected in the OMZ core and sulfide-oxidizers are abundant there (Stevens and Ulloa, 2008; Canfield et al., 2010). Instead, our results suggest that the accumulation of more than $0.5 \mu \mathrm{mol} \mathrm{kg}{ }^{-1}$ nitrite is a robust indicator of oxygen depletion to the low nanomolar range, at least in the Eastern South Pacific.

While we argue that anoxia is a normal phenomenon, the detection at one location of $10-50 \mathrm{nmol} \mathrm{kg}^{-1}$ oxygen associated with a disturbance of the typical stratification through most of the OMZ core (Fig. 3(b) and Fig. 4), emphasizes that such events may also be important in the OMZ system. This calls for investigation of the frequency of disturbances and their associated oxygen dynamics. Also the low but highly fluctuating oxygen concentrations with thin layers of complete depletion observed above the OMZ core off Peru (Figs. 3-5) indicate a highly dynamic oxygen regime with the potential for coupling of aerobic and anaerobic processes, depending on the temporal response of the processes to changes in oxygen availability. Investigations of these issues should focus on oxygen in the nanomolar range, which is a great challenge both analytically and experimentally due to the risk of contamination with oxygen from the atmosphere (De Brabandere et al., 2012).

Our measurements indicate that aerobic processes proceed efficiently to low nanomolar oxygen concentrations, which suggests that the anaerobic processes that lead to $\mathrm{N}_{2}$ production in the OMZ may be competitively restricted to much lower oxygen levels than previously assumed. This does not exclude $\mathrm{N}_{2}$ production in the presence of small amounts of oxygen in dynamic systems where active anaerobic populations are mixed into oxic waters (Jensen et al., 2008; Kalvelage et al., 2011). Also, a unique oxygen threshold for anaerobic processes may not be applicable across all OMZ waters, because the sensitivity to oxygen may vary among processes and be influenced by factors such as the availability of reduced substrate, and because organic aggregates may harbour microniches of variable size depending on the bulk oxygen concentration (Ploug, 2001). Still, the discrepancy between our results and the anaerobic thresholds of 0.7$20 \mu \mathrm{mol} \mathrm{L}^{-1}$ oxygen used so far in biogeochemical budgets and models of OMZs (see Karstensen et al., 2008; Paulmier Ruiz-Pino, 2009) is remarkable. A thorough revision of this important parameter is required and is particularly pertinent in view of the forecasted changes in oceanic oxygen concentrations and the burgeoning research in OMZs and marine dead zones. Oxygen determination in the low nanomolar range is the key to progress for in situ measurements and for detailed physiological studies in the laboratory.

\section{Acknowledgements}

We thank P.G. Sørensen and F. Knudsen for technical assistance. We also thank the master and crew of HDMS Vædderen for their help and hospitality and the Danish Expedition Foundation for providing shiptime, and we thank the scientific party for cooperation during sampling. Financial support was given by Danish Natural Science Research Council and the Danish National Research Foundation. The present work was carried out as part of the Galathea 3 Expedition under the auspices of the Danish Expedition Foundation. This is Galathea 3 contribution no. P89.

\section{References}

Aristegui, J., Agusti, S., Middelburg, J.J., Duarte, C.M., 2005. Respiration in the mesopelagic and bathypelagic zones of the oceans. In: del Giorgio, P.A., Williams, P.J.l.B. (Eds.), Respiration in Aquatic Ecosystems. Oxford University Press, Oxford, pp. 181-205.

Bange, H.W., 2008. Gaseous nitrogen compounds ( $\mathrm{NO}, \mathrm{N}_{2} \mathrm{O}, \mathrm{N}_{2}, \mathrm{NH}_{3}$ ) in the ocean. In: Capone, D.G., Bronk, D.A., Mulholland, M.R., Carpenter, E.J. (Eds.), Nitrogen in the Marine Environment. Elsevier, Amsterdam, pp. 51-94.

Betlach, M.R., Tiedje, J.M., 1981. Kinetic Explanation for accumulation of nitrite, nitric-oxide, and nitrous-oxide during bacterial denitrification. Appl. Environ. Microbiol. 42, 1074-1084.

Bonin, P., Gilewicz, M., Bertrand, J.C., 1989. Effects of oxygen on each step of denitrification on Pseudomonas nautica. Can. J. Microbiol. 35, 1061-1064.

Braman, R.S., Hendrix, S.A., 1989. Nanogram nitrite and nitrate determination in environmental and biological materials by vanadium(III) reduction with chemi-luminescence detection. Anal. Chem. 61, 2715-2718.

Canfield, D.E., Stewart, F.J., Thamdrup, B., De Brabandere, L., Dalsgaard, T., Delong, E.F., Revsbech, N.P., Ulloa, O., 2010. A cryptic sulfur cycle in oxygen-minimumzone waters off the Chilean coast. Science 330,1375-1378.

Clement, B.G., Luther, G.W., Tebo, B.M., 2009. Rapid, oxygen-dependent microbial $\mathrm{Mn}$ (II) oxidation kinetics at sub-micromolar oxygen concentrations in the Black Sea suboxic zone. Geochim. Cosmochim. Acta 73, 1878-1889.

Cline, J.D., Richards, F.A., 1972. Oxygen deficient conditions and nitrate reduction in Eastern Tropical North-Pacific ocean. Limnol. Oceanogr. 17, 885-900. 
Codispoti, L.A., 2007. An oceanic fixed nitrogen sink exceeding $400 \mathrm{Tg} \mathrm{N} \mathrm{a}^{-1} \mathrm{vs}$. the concept of homeostasis in the fixed-nitrogen inventory. Biogeosciences 4 , 233-253.

Codispoti, L.A., Christensen, J.P., 1985. Nitrification, denitrification and nitrousoxide cycling in the Eastern Tropical South-Pacific ocean. Mar. Chem. 16, 277-300.

Codispoti, L.A., Packard, T.T., 1980. Denitrification rates in the Eastern Tropical South-Pacific. J. Mar. Res. 38, 453-477.

Codispoti, L.A., Brandes, J.A., Christensen, J.P., Devol, A.H., Naqvi, S.W.A., Paerl, H.W., Yoshinary, T., 2001. The oceanic fixed nitrogen and nitrous oxide budgets: moving targets as we enter the anthropocene? Sci. Mar. 65 (suppl. 2), 85-105.

Codispoti, L.A., Yoshinari, T., Devol, A.H., 2005. Suboxic respiration in the oceanic water column. In: del Giorgio, P.A., Williams, P.J.l.B. (Eds.), Respiration in Aquatic Ecosystems. Oxford University Press, Oxford, pp. 225-247.

Contreras, M.L., Escamilla, J.E., Del Arenal, I.P., Davila, J.R., D'Mello, R., Poole, R.K. 1999. An unusual cytochrome $o$ '-type cytochrome $c$ oxidase in a Bacillus cereus cytochrome $a(3)$ mutant has a very high affinity for oxygen. Microbiol. UK 145 1563-1573.

Copin-Montegut, C., Raimbault, P., 1994. The Peruvian upwelling near $15^{\circ} \mathrm{S}$ in August 1986 - results of continuous measurements of physical and chemical properties between 0 and $200 \mathrm{~m}$ depth. Deep Sea Res. Part I 41, 439-467.

Czeschel, R., Stramma, L., Schwarzkopf, F.U., Giese, B.S., Funk, A., Karstensen, J., 2011. Middepth circulation of the Eastern Tropical South Pacific and its link to the oxygen minimum zone. J. Geophys. Res. Oceans 116, C01015. doi:10.1029/ 2010JC006565.

Dalsgaard, T., Bak, F., 1994. Nitrate reduction in a sulfate-reducing bacterium, Desulfovibrio desulfuricans, isolated from rice paddy soil - sulfide inhibition, kinetics, and regulation. Appl. Environ. Microbiol. 60, 291-297.

Dalsgaard, T., Canfield, D.E., Petersen, J., Thamdrup, B., Acuña-Gonzalez, J., 2003. N production by the anammox reaction in the anoxic water column of Golfo Dulce, Costa Rica. Nature 422, 606-608.

De Brabandere, L., Thamdrup, B., Revsbech, N.P., Foadi, R., 2012. A critical assessment of the occurrence and extend of oxygen contamination during anaerobic incubations utilizing commercially available vials. J. Microbiol. Methods 88, 147-154

Devol, A.H., 1978. Bacterial oxygen-uptake kinetics as related to biologica processes in oxygen deficient zones of oceans. Deep Sea Res. 25, 137-146.

Diaz, R.J., Rosenberg, R., 2008. Spreading dead zones and consequences for marine ecosystems. Science 321, 926-929.

Farías, L., Castro-Gonzalez, M., Cornejo, M., Charpentier, J., Faundez, J., Boontanon, N., Yoshida, N., 2009. Denitrification and nitrous oxide cycling within the upper oxycline of the Eastern Tropical South Pacific oxygen minimum zone. Limnol. Oceanogr. 54, 132-144.

Fiadeiro, M., Strickland, J.D.H., 1968. Nitrate reduction and occurrence of a deep nitrite maximum in the ocean off the west coast of South America. J. Mar. Res. 26, 187-201.

Föllmi, K.B., 1996. The phosphorus cycle, phosphogenesis and marine phosphaterich deposits. Earth Sci. Rev. 40, 55-124.

Fonseca, T.R., 1989. An overview of the poleward undercurrent and upwelling along the Chilean coast. In: Neshyba, S.J., Mooers, C.N.K., Smith, R.L., Barber, R.T. (Eds.), Poleward Flow Along Eastern Ocean Boundaries. Springer-Verlag, New York, pp. 203-218.

Fossing, H., Gallardo, V.A., Jørgensen, B.B., Hüttel, M., Nielsen, L.P., Schulz, H., Canfield, D.E., Forster, S., Glud, R.N., Gundersen, J.K., Küver, J., Ramsing, N.B. Teske, A., Thamdrup, B., Ulloa, O., 1995. Concentration and transport of nitrate by the mat-forming sulphur bacterium Thioploca. Nature 374 , 713-715.

Froelich, P.N., Arthur, M.A., Burnett, W.C., Deakin, M., Hensley, V., Jahnke, R., Kaul, L., Kim, K.H., Roe, K., Soutar, A., Vathakanon, C., 1988. Early diagenesis of organic matter in Peru continental-margin sediments - phosphorite precipitation. Mar. Geol. 80, 309-343.

Füssel, J., Lam, P., Lavik, G., Jensen, M.M., Holtappels, M., Günter, M., Kuypers, M.M.M. Nitrite oxidation in the Namibian oxygen minimum zone. ISME J, doi:10.1038/ismej.2011.178, in press.

Goering, J.J., Cline, J.D., 1970. A note on denitrification in seawater. Limnol. Oceanogr. 15, 306-309.

Grasshoff, K., 1983. Determination of nitrite. In: Grasshoff, K., Ehrhardt, M. Kremling, K. (Eds.), Methods of Seawater Analysis. Verlag Chemie, Weinheim, pp. $139-142$.

Gruber, N., 2008. The marine nitrogen cycle: overview and challenges. In: Capone, D.G., Bronk, D.A., Mulholland, M.R., Carpenter, E.J. (Eds.), Nitrogen in the Marine Environment. Elsevier, Amsterdam, pp. 1-50.

Helly, J.J., Levin, L.A., 2004. Global distribution of naturally occurring marine hypoxia on continental margins. Deep Sea Res. Part I 51, 1159-1168.

Høgslund, S., Revsbech, N.P., Cedhagen, T., Nielsen, L.P., Gallardo, V.A., 2008 Denitrification, nitrate turnover, and aerobic respiration by benthic foraminiferans in the oxygen minimum zone off Chile. J. Exp. Mar. Biol. Ecol. 359, 85-91.

Huyer, A., Gilbert, W.E., Schramm, R., Barstow, D., 1978. CTD observations off the coast of Peru, R/V Melville, 4 March - 22 May 1977, and R/V Columbus Iselin, 5 April - 19 May 1977. Data Report 71, School of Oceanography, Oregon State University, Corvallis, OR.

Jensen, M.M., Kuypers, M.M.M., Lavik, G., Thamdrup, B., 2008. Rates and regulation of anaerobic ammonium oxidation and denitrification in the Black Sea. Limnol. Oceanogr. 53, 23-36.
Jensen, M.M., Lam, P., Revsbech, N.P., Nagel, B., Gaye, B., Jetten, M.S.M., Kuypers, M.M.M., 2011. Intensive nitrogen loss over the Omani Shelf due to anammox coupled with dissimilatory nitrite reduction to ammonium. ISME J. 5, 1660-1670.

Kalvelage, T., Jensen, M.M., Contreras, S., Revsbech, N.P., Lam, P., Günter, M. LaRoche, J., Lavik, G., Kuypers, M.M.M., 2011. Oxygen sensitivity of anammox and coupled $\mathrm{N}$-cycle processes in Oxygen Minimum Zones. PLoS ONE 6 , e29299. doi:10.1371/journal.pone.0029299.

Karstensen, J., Stramma, L., Visbeck, M., 2008. Oxygen minimum zones in the Eastern Tropical Atlantic and Pacific oceans. Progr. Oceanogr. 77, 331-350.

Keeling, R.F., Körtzinger, A., Gruber, N., 2010. Ocean deoxygenation in a warming world. Annu. Rev. Mar. Sci. 2, 199-229.

Lam, P., Jensen, M.M., Lavik, G., McGinnis, D.F., Muller, B., Schubert, C.J., Amann, R., Thamdrup, B., Kuypers, M.M.M., 2007. Linking crenarchaeal and bacterial nitrification to anammox in the Black Sea. Proc. Nat. Acad. Sci. U.S.A. 104 7104-7109.

Lam, P., Lavik, G., Jensen, M.M., van de Vossenberg, J., Schmid, M., Woebken, D. Dimitri, G., Amann, R., Jetten, M.S.M., Kuypers, M.M.M., 2009. Revising the nitrogen cycle in the Peruvian oxygen minimum zone. Proc. Nat. Acad. Sci. U.S.A. 106, 4752-4757.

Lipschultz, F., Wofsy, S.C., Ward, B.B., Codispoti, L.A., Friedrich, G., Elkins, J.W., 1990. Bacterial transformations of inorganic nitrogen in the oxygen-deficient waters of the Eastern Tropical South-Pacific Ocean. Deep Sea Res. Part A 37 $1513-1541$.

Lloyd, D., 2002. Noninvasive methods for the investigation of organisms at low oxygen levels. Adv. Appl. Microbiol. 51, 155-183.

Morrison, J.M., Codispoti, L.A., Smith, S.L., Wishner, K., Flagg, C., Gardner, W.D. Gaurin, S., Naqvi, S.W.A., Manghnani, V., Prosperie, L., Gundersen, J.S., 1999. The oxygen minimum zone in the Arabian Sea during 1995. Deep Sea Res. Part II 46, 1903-1931.

Naqvi, S.W.A., Narvekar, P.V., Desa, E., 2005. Coastal biogeochemical processes in the North Indian Ocean (14, S-W). In: Robinson, A.R., Brink, K.H. (Eds.), The Sea, 14B. Harvard University Press, Cambridge, MA, pp. 723-781.

Naqvi, S.W.A., Bange, H.W., Farias, L., Monteiro, P.M.S., Scranton, M.I., Zhang, J., 2010. Marine hypoxia/anoxia as a source of $\mathrm{CH}_{4}$ and $\mathrm{N}_{2} \mathrm{O}$. Biogeosciences 7 , 2159-2190.

NASA Earth Observations: Sea surface temperature anomaly (AMSR-E), <http:// neo.sci.gsfc.nasa.gov/ >, last access: 11 December, 2011.

NWS Climate Prediction Center Internet Team: El Niño Southern Oscillation (ENSO): Historical El Nino/La Nina episodes (1950-present), U.S. National Weather Service, 〈http://www.cpc.noaa.gov/products/analysis_monitoring/ ensostuff/ensoyears.shtml $>$, last access: 11 December, 2011.

OceanColor Web: Level 3 browser, Aqua MODIS chlorophyll concentration, $\langle$ http://oceancolor.gsfc.nasa.gov/cgi/l3 $\rangle$, last access: 11 December, 2011.

Paulmier, A., Ruiz-Pino, D., 2009. Oxygen minimum zones (OMZs) in the modern ocean. Progr. Oceanogr. 80, 113-128.

Paulmier, A., Ruiz-Pino, D., Garcon, V., Farias, L., 2006. Maintaining of the Eastern South Pacific Oxygen Minimum Zone (OMZ) off Chile. Geophys. Res. Lett. 33 L20601. doi:10.1029/2006GL026801.

Ploug, H., 2001. Small-scale oxygen fluxes and remineralization in sinking aggregates. Limnol. Oceanogr. 46, 1624-1631.

Rabalais, N.N., Diaz, R.J., Levin, L.A., Turner, R.E., Gilbert, D., Zhang, J., 2010. Dynamics and distribution of natural and human-caused hypoxia. Biogeosciences 7, 585-619.

Revsbech, N.P., Larsen, L.H., Gundersen, J., Dalsgaard, T., Ulloa, O., Thamdrup, B. 2009. Determination of ultra-low oxygen concentrations in oxygen minimum zones by the STOX sensor. Limnol. Oceanogr. Methods. 7, 371-381.

Revsbech, N.P., Thamdrup, B., Dalsgaard, T., Canfield, D.E., 2011. Construction of Stox oxygen sensors and their application for determination of $\mathrm{O}_{2}$ concentrations in oxygen minimum zones. In: Klotz, M.G. (Ed.), Methods in Enzymology: Research on Nitrification and Related Processes, Vol 486, Part A, pp. 325-341.

Richards, F.A., 1965. Anoxic basins and fjords. In: Riley, J.P., Skirrow, G. (Eds.), Chemical Oceanography. Academic Press, London, pp. 611-643.

Schmidt, J., 1925. On the contents of oxygen in the ocean on both sides of Panama. Science 61, 592-593.

Schneider, W., Fuenzalida, R., Rodriguez-Rubio, E., Garces-Vargas, J., Bravo, L. 2003. Characteristics and formation of Eastern South Pacific intermediate water. Geophys. Res. Lett. 32, 15602-15605.

Schlitzer, R., 2010: Ocean Data View, 〈http://odv.awi.de〉.

Seibel, B.A., 2011. Critical oxygen levels and metabolic suppression in oceanic oxygen minimum zones. J. Exp. Biol. 214, 326-336.

Silva, N., Rojas, N., Fedele, A., 2009. Water masses in the Humboldt Current System: properties, distribution, and the nitrate deficit as a chemical water mass tracer for Equatorial Subsurface Water off Chile. Deep Sea Res. Part II 56, 992-1008.

Stevens, H., Ulloa, O., 2008. Bacterial diversity in the oxygen minimum zone of the Eastern Tropical South Pacific. Environ. Microbiol. 10, 1244-1259.

Stolper, D.A., Revsbech, N.P., Canfield, D.E., 2010. Aerobic growth at nanomolar oxygen concentrations. Proc. Nat. Acad. Sci. U.S.A. 107, 18755-18760.

Stramma, L., Johnson, G.C., Sprintall, J., Mohrholz, V., 2008. Expanding oxygenminimum zones in the tropical oceans. Science 320, 655-658.

Stramma, L., Schmidtko, S., Levin, L.A., Johnson, G.C., 2010. Ocean oxygen minima expansions and their biological impacts. Deep Sea Res. Part I 57 , 587-595. 
Thamdrup, B., Dalsgaard, T., Jensen, M.M., Ulloa, O., Farias, L., Escribano, R., 2006. Anaerobic ammonium oxidation in the oxygen-deficient waters off northern Chile. Limnol. Oceanogr. 51, 2145-2156.

Ward, B.B., Capone, D.G., Zehr, J.P., 2007. What's new in the nitrogen cycle? Oceanography 20, 101-109.

Ward, B.B., Devol, A.H., Rich, J.J., Chang, B.X., Bulow, S.E., Naik, H., Pratihary, A., Jayakumar, A., 2009. Denitrification as the dominant nitrogen loss process in the Arabian Sea. Nature 461, 78-81.

Wooster, W.S., Gilmartin, M., 1961. The Peru-Chile Undercurrent. J. Mar. Res. 19, 97-122.
Wooster, W.S., Chow, T.J., Barrett, I., 1965. Nitrite distribution in Peru Current waters. J. Mar. Res. 23, 210-221.

Wyrtki, K., 1962. The oxygen minima in relation to ocean circulation. Deep Sea Res 9, $11-23$.

Wyrtki, K., 1967. Circulation and water masses in the Eastern Equatorial Pacific Ocean. Int. J. Oceanol. Limnol. 1, 117-147.

Zuta, S., Guillen, O., 1970. Oceanografía de las aguas costeras del Perú. Bol. Inst. Mar. Perú 2, 157-324. 